\title{
ANALISIS IN SILICO SENYAWA AKTIF Sprirulina platensis SEBAGAI INHIBITOR TIROSINASE
}

\author{
Prayoga Pannindriya ${ }^{1}$, Mega Safithri ${ }^{1,3 *}$, Kustiariyah Tarman ${ }^{2,3}$ \\ ${ }^{1}$ Departemen Biokimia, FMIPA IPB, Kampus IPB Darmaga, Jalan Meranti, Dramaga, Kabupaten Bogor \\ 16680 Jawa Barat. Telepon (0251) 8423267 \\ ${ }^{2}$ Departemen Teknologi Hasil Perairan, FPIK IPB, Jalan Agatis, Kampus IPB Dramaga, Kabupaten Bogor, \\ 16680 Jawa Barat. Telepon (0251) 8622915 \\ ${ }^{3}$ Divisi Bioteknologi Kelautan, PKSPL LPPM IPB
}

Diterima: 03 November 2020/Disetujui: 30 Maret 2021

*Korespondensi: safithri@apps.ipb.ac.id

Cara sitasi: Pannindriya P, Safithri M, Tarman K. Analisis in silico senyawa aktif Spirulina platensis sebagai inhibitor tirosinase. Jurnal Pengolahan Hasil Perikanan Indonesia. 24(1): 70-77.

\begin{abstract}
Abstrak
Hiperpigmentasi merupakan kondisi ketika melanin diproduksi secara berlebih sehingga menimbulkan bercak-bercak pada kulit. Kondisi ini selain menyebabkan masalah estetika juga meningkatkan produksi reactive oxygen species pada kulit. Salah satu cara menangani hiperpigmentasi adalah melalui inhibisi enzim kunci sintesis melanin yaitu tirosinase. Spirulina platensis adalah mikroalga yang telah banyak digunakan sebagai suplemen maupun obat karena kandungan nutrisinya yang tinggi. Ekstrak S. platensis telah terbukti secara in vitro memiliki kemampuan menginhibisi enzim tirosinase. Penelitian ini bertujuan untuk mencari senyawa aktif pada S. platensis yang berpotensi sebagai inhibitor enzim tirosinase. Senyawa-senyawa aktif yang terdapat pada $S$. platensis ditelusuri melalui studi pustaka kemudian diseleksi berdasarkan afinitas, toksisitas, dan aturan Lipinski. Analisis penambatan molekuler dilakukan dengan senyawa yang terpilih terhadap enzim tirosinase dengan asam kojat sebagai ligan kontrol. Hasil penambatan molekuler menunjukkan bahwa kaempferol paling berpotensi sebagai inhibitor tirosinase karena memiliki $\Delta \mathrm{G}$ paling negatif yaitu $-7,0 \mathrm{kkal} / \mathrm{mol}$ sehingga memiliki afinitas terbesar terhadap enzim tirosinase.
\end{abstract}

Kata kunci: penambatan molekuler, Spirulina platensis, tirosinase

\section{In Silico Analysis of Spirulina platensis Active Compounds as Tyrosinase Inhibitor}

\begin{abstract}
Hyperpigmentation is a condition when melanin is overproduced, causing spots on the skin. This condition apart from causing aesthetic problems, can also increase the production of reactive oxygen species at the skin. One way to deal with hyperpigmentation is through inhibiting the key enzyme for melanin synthesis which is tyrosinase. Spirulina platensis is a microalgae that has been widely used as a supplement and medicine because of its high nutritional content. S. platensis extract has been proven in vitro to have the ability inhibiting the tyrosinase enzyme. This study aimed to find active compounds in S. platensis that have the potential as tyrosinase enzyme inhibitors. The active compounds found in S. platensis were explored through literature studies and then selected based on affinity, toxicity, and Lipinski's Rule. Molecular docking analysis was carried out with selected compounds against the tyrosinase enzyme with kojic acid as the control ligand. The results of molecular docking showed that kaempferol has the best potential as tyrosinase inhibitor since it has the most negative $\Delta \mathrm{G}$ thus has the best affinity with the tyrosinase enzyme.
\end{abstract}

Keyword: molecular docking, Spirulina platensis, tyrosinase 


\section{PENDAHULUAN}

Hiperpigmentasi adalah kondisi ketika melanin diproduksi secara berlebihan sehingga menyebabkan munculnya bercakbercak gelap pada kulit. Kondisi ini dapat terjadi karena berbagai penyebab seperti sinar UV, inflamasi, hormon, maupun obat-obatan (Reddy dan Vashi 2018). Bercak pigmentasi yang muncul karena hiperpigmentasi dianggap sebagai masalah estetika. Selain masalah estetika, kondisi ini juga meningkatkan produksi reactive oxygen species (ROS) yang dapat menyebabkan kerusakan kulit. Penanganan hiperpigmentasi dapat dilakukan melalui inhibisi enzim tirosinase. Tirosinase merupakan enzim kunci dalam proses sintesis melanin sehingga jika enzim ini dihambat, produksi melanin akan terhambat pula (Costa et al. 2017).

Spirulina platensis adalah mikroalga yang memiliki banyak peranan baik di bidang pangan maupun medis karena nilai nutrisi protein, vitamin, asam lemak esensial, dan mineral yang tinggi (Lupatini et al. 2017). Kandungan bioaktif dari S. platensis penting untuk menjaga kesehatan kulit dari kerusakan akibat oksidasi, inflamasi, sistem imun, dan penuaan. Kandungan nutrisinya yang tinggi membuat $S$. platensis dapat dijadikan sebagai bahan berbagai suplemen maupun obat untuk mengatasi penyakit (Costa et al. 2017).

Ekstrak etanol S. platensis secara in vitro telah dilaporkan aktivitas inhibisi tirosinase (Sahin 2018). Oleh karena itu, diperlukan pula analisis lebih lanjut secara in silico untuk mengetahui senyawa dalam ekstrak yang berperan dalam aktivitas inhibisi tersebut. Salah satu analisis in silico yang dapat digunakan adalah penambatan molekuler. Penambatan molekuler merupakan salah satu metode yang dilakukan untuk mempelajari interaksi yang terjadi antara inhibitor dengan sisi aktif enzim (Khan et al. 2019). Metode penambatan molekuler dapat menganalisis posisi suatu senyawa terhadap enzim dan ikatan kimia yang terlibat sehingga aktivitas senyawa terhadap suatu enzim dapat diprediksi (Mustarichie et al. 2013). Penelitian ini bertujuan untuk mencari senyawa aktif pada S. platensis yang paling berpotensi sebagai inhibitor enzim tirosinase.

\section{BAHAN DAN METODE Bahan dan Alat}

Alat yang digunakan dalam penelitian ini adalah laptop HP dengan spesifikasi processor Intel(R) Core(TM) i5, RAM 4GB, dan OS Windows 10; perangkat lunak Marvin View 6, Discovery Studio Visualizer 2017, PyRx, Autodock Vina, PyMOL, dan Ligplot+ 1.5.4.

Bahan yang digunakan dalam penelitian ini adalah struktur 3D enzim tirosinase (kode PDB: 5i38), struktur 3D dari 31 senyawa aktif S. platensis yang diperoleh dari hasil studi literatur, dan struktur 3D dari asam kojat sebagai ligan pembanding.

\section{Metode Penelitian \\ Preparasi struktur ligan dan reseptor}

Senyawa-senyawa aktif yang terkandung dalam S. platensis ditelusuri melalui studi literatur (Table 1). Struktur senyawa yang diperoleh diunduh dari laman web PubChem (pubchem.ncbi.nlm.nih.gov).Ligan ditambahkan atom hidrogen polar menggunakan perangkat lunak Discovery Studio.

Reseptor struktur 3D enzim tirosinase (kode PDB: 5i38) diunduh dari situs Protein Data Bank (rcsb.org) dalam format .pdb. Preparasi dilakukan menggunakan perangkat lunak Discovery Studio. Enzim tirosinase memiliki dua rantai yaitu A dan B. Rantai A dipilih sedangkan rantai B dihapus. Selanjutnya molekul air dan hetero atom dihilangkan. Preparasi dilanjutkan dengan perangkat lunak Autodock Vina untuk dilakukan penambahan atom hidrogen polar dan perhitungan muatan Gasteiger.

\section{Penapisan virtual senyawa aktif S. platensis}

Sebanyak 31 ligan uji yang merupakan senyawa aktif pada S. platensis dianalisis karakteristik, toksisitas, dan nilai afinitasnya terhadap reseptor tirosinase (kode PDB: 5i38). Analisis afinitas dilakukan menggunakan perangkat lunak PyRx. Analisis karakteristik ligan menggunakan server web http://scfbioiitd.res.in/software/drugdesign/lipinski.jsp. Analisis toksisitas berdasarkan parameter karsinogenisitas, inhibisi human Ether-AGo-Go Related Gene (hERG), dan toksisitas oral akut menggunakan situs http://lmmd. 
Table 1 Bioactive compounds of S. platensis

\begin{tabular}{|c|c|}
\hline Bioactive compounds & Reference \\
\hline Tertradecane & Ozdemir et al. (2004) \\
\hline a-Ionene & Ozdemir et al. (2004) \\
\hline Pentadecane & Ozdemir et al. (2004) \\
\hline 2-hexadecane & Ozdemir et al. (2004) \\
\hline Hexadecane & Ozdemir et al. (2004) \\
\hline Hexadecanenitrile & Ozdemir et al. (2004) \\
\hline $6(Z), 9(E)$ - heptadiene & Ozdemir et al. (2004) \\
\hline 8 - heptadecane & Ozdemir et al. (2004) \\
\hline Heptadecane & Ozdemir et al. (2004) \\
\hline Neophytadiene & Ozdemir et al. (2004) \\
\hline Pentadecanenitrile & Ozdemir et al. (2004) \\
\hline 9,12-octadecadienoic acid & Ozdemir et al. (2004) \\
\hline Hexadecanoic acid & Ozdemir et al. (2004) \\
\hline Isophytol & Ozdemir et al. (2004) \\
\hline Phytol & Ozdemir et al. (2004) \\
\hline Gallic Acid & da Silva et al. (2017); Sahin (2018) \\
\hline Vanillic acid & da Silva et al. (2017); Klejdus et al. (2009) \\
\hline Syringic acid & da Silva et al. (2017); Sahin (2018); Klejdus et al. (2009) \\
\hline p-coumaric acid & Sahin (2018); Papalia et al. (2019) \\
\hline Quercetin & Sahin (2018); Papalia et al. (2019) \\
\hline Cinnamic acid & Sahin (2018) \\
\hline Caffeic acid & Sahin (2018); Papalia et al. (2019); Klejdus et al. (2009) \\
\hline Ferulic acid & da Silva et al. (2017); Papalia et al. (2019) \\
\hline Chlorogenic acid & Klejdus et al. (2009) \\
\hline 4-hydroxybenzaldehyde & Klejdus et al. (2009) \\
\hline 3,4-dihydroxybenzaldehyde & Klejdus et al. (2009) \\
\hline p-Hydroxybenzoic acid & Papalia et al. (2019); Klejdus et al. (2009) \\
\hline Genistein & Papalia et al. (2019) \\
\hline Kaempferol & Papalia et al. (2019) \\
\hline Catechin & da Silva et al. (2017); Papalia et al. (2019) \\
\hline Epicatechin & da Silva et al. (2017) \\
\hline
\end{tabular}

ecust.edu.cn/admetsar2/ berdasarkan Yang et al. 2019. Analisis afinitas menggunakan perangkat lunak PyRx dengan gridbox yang diperoleh dari hasil validasi.

\section{Validasi metode}

Validasi penambatan molekuler dilakukan menggunakan perangkat lunak Autodock Vina. Ligan kontrol yaitu asam kojat yang tertambat pada reseptor digunakan untuk validasi dengan gridbox dengan koordinat $\mathrm{x}=2.127 ; \mathrm{y}=101.824 ; \mathrm{z}=25.596$, dengan ukuran gridbox 10x10x10 ̊, dan spacing sebesar $1 \AA$. Validasi dilakukan sebanyak 20 kali hingga diperoleh hasil validasi terbaik dengan nilai root mean square deviation (RMSD) di bawah 2,5 . 


\section{Penambatan molekuler ligan terhadap tirosinase}

Penambatan molekuler dilakukkan menggunakan perangkat lunak Autodock Vina dengan metode Trott dan Olson (2009) dengan gridbox yang diperoleh dari proses validasi. Proses penambatan molekuler dijalankan menggunakan Command Prompt. Hasil penambatan molekuler berupa fail dengan format .pdbqt yang selanjutnya dianalisis.

\section{Analisis hasil penambatan molekuler}

Nilai konstanta inhibisi (Ki) ligan terhadap reseptor dapat diperoleh dari nilai $\Delta \mathrm{G}$ menggunakan persamaan berikut:

$\Delta \mathrm{G}=\mathrm{RT} \ln (\mathrm{Ki})$

dengan

$\mathrm{T}=298 \mathrm{~K}$;

$\mathrm{R}=1,987 \mathrm{kkal} \cdot \mathrm{K}^{-1} \cdot \mathrm{mol}^{-1}$

Ligan hasil penambatan molekuler digabungkan dengan reseptor menggunakan perangkat lunak Discovery Studio lalu disimpan dengan format .pdb. Ikatan kimia dengan residu asam amino reseptor yang terbentuk dilihat menggunakan perangkat lunak Ligplot+ kemudian digunakan pula perangkat lunak PyMOL untuk membuat visualisasi posisi ligan terhadap reseptor dan posisi asam amino yang berinteraksi dengan ligan.

HASIL DAN PEMBAHASAN Seleksi Senyawa Aktif berdasarkan Penapisan Virtual, Aturan Lipinski, dan Uji Toksisitas

Studi literatur senyawa aktif $S$. platensis menghasilkan sebanyak 31 senyawa aktif tercantum pada Table 1 beserta sumber pustakanya. Struktur 3D senyawa aktif S. platensis yang diunduh dari situs Pubcem diseleksi sehingga diperoleh 7 ligan terbaik berdasarkan penapisan virtual, aturan Lipinski, dan analisis toksisitas yang hasilnya terdapat pada Table 2. Senyawa-senyawa aktif diseleksi terlebih dahulu toksisitasnya berdasarkan struktur virtual setiap senyawa untuk menghindari adanya efek samping yang tidak diinginkan (Roncaglioni et al. 2013). Analisis toksisitas meliputi analisis karsinogenisitas, analisis inhibisi HumanEther-Ä-Go-Go Related Gene (hERG), dan dosis toksisitas oral akut.

Karsinogenisitas merupakan sifat atau kemampuan suatu bahan untuk menyebabkan terjadinya neoplasia (pertumbuhan jaringan baru) (Klaunig 2013). Toksisitas akut adalah paparan terhadap suatu bahan dalam waktu kurang dari 24 jam. Salah satu metode pengukuran tingkat tokisisitas akut adalah dengan penentuan nilai $\mathrm{LD}_{50}$ (Eaton dan Gilbert 2013). Toksisitas akut terbagi menjadi 5 tingkatan berdasarkan nilai $\mathrm{LD}_{50}$ yaitu: Ia (<5 mg/kg), Ib (5-50 mg/kg), II (50-500 mg/ $\mathrm{kg})$, III (>500 mg/kg), dan IV (>2000 mg/kg) (Costa 2013). hERG adalah salah satu faktor penting dalam penemuan obat baru. Jika gen ini terinhibisi, arrhythmia pada jantung akan terjadi yang dapat berakibat fatal. Oleh karena itu, analisis inhibisi hERG wajib dilakukan dalam proses pengembangan obat baru (Di dan Kerns 2016).

Senyawa juga diuji karakteristiknya berdasarkan Aturan Lipinski. Aturan Lipinski menyatakan bahwa senyawa dengan absorpsi dan permeabilitas yang buruk adalah yang

Table 2 Selected ligand's characteristics based on affinity, Lipinski's rule, and oral acute toxicity test

\begin{tabular}{lrrrrr}
\hline \multicolumn{1}{c}{ Compounds } & \multicolumn{1}{c}{$\begin{array}{c}\text { L } \\
(\mathrm{kcal} / \mathrm{mol})\end{array}$} & $\begin{array}{c}\text { Lipinski's rule } \\
\text { violation }\end{array}$ & Carcinogenity & $h E R G$ inhibition & $\begin{array}{c}\text { Oral acute } \\
\text { toxicity level }\end{array}$ \\
\hline Caffeic acid & -6.4 & 0 & Non-carcinogen & Weak Inhibitor & IV \\
Cinnamic acid & -6.1 & 0 & Non-carcinogen & Weak Inhibitor & III \\
Ferulic acid & -5.9 & 0 & Non-carcinogen & Weak Inhibitor & IV \\
Genistein & -5.8 & 0 & Non-carcinogen & Weak Inhibitor & II \\
Kaempferol & -7.0 & 0 & Non-carcinogen & Weak Inhibitor & II \\
p-coumaric acid & -6.1 & 0 & Non-carcinogen & Weak Inhibitor & III \\
Vanillic acid & -6.0 & 0 & Non-carcinogen & Weak Inhibitor & III \\
\hline
\end{tabular}


memiliki lebih dari 5 donor ikatan hidrogen, 10 akseptor ikatan hidrogen, bobot molekul lebih dari 500, dan nilai $\log \mathrm{P}$ lebih dari 5 (Lipinski et al. 1997; Ghose et al. 1999). Afinitas setiap senyawa terhadap reseptor tirosinase dianalisis sehingga diperoleh nilai $\Delta \mathrm{G}$. Semakin negatif nilai $\Delta \mathrm{G}$, semakin tinggi afinitas suatu senyawa dengan reseptor (Balle dan Liljefors 2016).

Ketujuh senyawa terbaik terpilih pada Table 2 adalah yang tidak memiliki pelanggaran pada aturan Lipinski dan tidak memiliki sifat karsinogenisitas maupun inhibisi hERG. Dua di antara senyawa uji yaitu asam kafeat dan asam ferulat memiliki tingkat toksisitas akut yang lebih rendah sedangkan genistein dan kaempferol menunjukkan toksisitas yang lebih tinggi.

\section{Penambatan Senyawa Aktif pada Tirosinase}

Tirosinase mengkatalisis tiga reaksi dalam sintesis melanin yaitu reaksi hidroksilasi tirosin menjadi 3,4-dihidroksifenilalanin (DOPA), oksidasi DOPA menjadi dopakuinon, dan reaksi 5,6-dihidroksiindol menjadi melanokrom. Reaksi yang melibatkan substrat tirosin dan DOPA terjadi pada sisi aktif yang sama pada tirosinase (Deri et al. 2016). Oleh karena itu, inhibisi enzim tirosinase akan menghambat seluruh proses sintesis tirosinase. Reaksi yang dikatalisis tirosinase adalah monooksigenasi dan oksidasi. Substrat tirosinase dapat berupa fenol yang akan mengalami monooksigenasi menjadi orto-quinon serta katekol yang akan

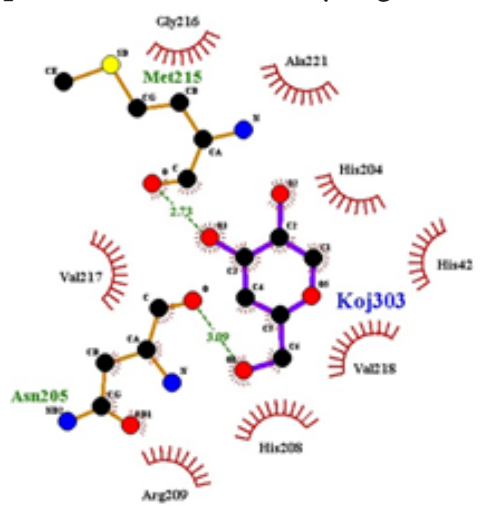

A mengalami oksidasi menjadi orto-quinon. Aktivitas katalitik ini berasal dari ikatan antara dioksigen dengan dua atom $\mathrm{Cu}(\mathrm{CuA}$ dan $\mathrm{CuB}$ ) pada sisi aktifnya (Ramsden dan Riley 2014).

Balle dan Liljefors 2016 menyatakan bahwa semakin negatif nilai $\Delta G$, semakin tinggi pula kecenderungan ligan dan reseptor untuk saling berikatan. Selain itu, semakin negatif nilai $\Delta G$, semakin rendah pula nilai konstanta inhibisi (Ki). Nilai Ki adalah konsentrasi inhibitor yang dibutuhkan untuk menurunkan setengah dari aktivitas enzim. Semakin kecil nilai Ki, semakin kuat inhibitor tersebut. Hasil penambatan molekuler pada Table 3 menunjukkan bahwa ligan uji yang memiliki nilai $\Delta G$ paling negatif adalah kaempferol yaitu $-7,0 \mathrm{kkal} / \mathrm{mol}$ dan yang memiliki \%BSS paling tinggi adalah asam kafeat dan asam vanilat yaitu $100 \%$. Oleh karena itu, kaempferol juga memiliki nilai Ki yang paling rendah juga yaitu sebesar 7,299 $\mu \mathrm{M}$. Nilai $\Delta \mathrm{G}$ dan Ki kaempferol dan ligan uji lainnya lebih rendah dari ligan kontrol yaitu asam kojat. Hal ini menunjukkan bahwa semua ligan uji khususnya kaempferol memiliki kemampuan untuk berikatan dengan reseptor lebih tinggi dari asam kojat.

Ligan kontrol asam kojat hasil penambatan molekuler berinteraksi dengan 10 residu asam amino yang delapan di antaranya berinteraksi secara hidrofobik, sedangkan dua lainnya berikatan hidrogen. Kaempferol berinteraksi dengan semua residu yang juga berinteraksi dengan asam kojat kecuali Met215 (Figure 1). Menurut Deri et al. (2016),

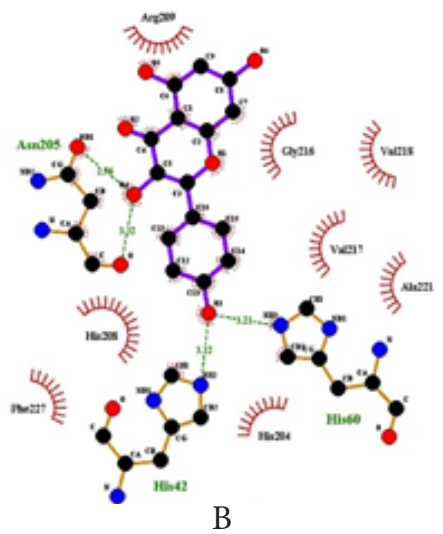

Figure $12 \mathrm{D}$ visualization of molecular docking result using Ligplot+. Red lines show hydrophobic interactions; green lines show hydrogen bonds. A) Amino acids interacted with kojic acid; b) Amino acids interacted with kaempferol 
Table 1 Bioactive compounds of S. platensis

\begin{tabular}{|c|c|c|c|c|c|c|c|c|}
\hline Ligan & $\mathrm{K}$ & 1 & 2 & 3 & 4 & 5 & 6 & 7 \\
\hline$\Delta \mathrm{G}(\mathrm{kcal} / \mathrm{mol})$ & -5.4 & -6.4 & -6.1 & -5.9 & -5.8 & -7.0 & -6.1 & -6.0 \\
\hline $\mathrm{Ki}(\mu \mathrm{M})$ & 108.988 & 20.117 & 33.397 & 46.824 & 55.444 & 7.299 & 33.397 & 39.747 \\
\hline \multirow{14}{*}{ Residue } & His42 & His42 & His 42 & His42 & His42 & His42 & His 42 & His42 \\
\hline & - & His60 & His60 & His60 & His60 & His60 & His60 & His60 \\
\hline & - & - & - & - & His69 & - & - & - \\
\hline & - & Pro201 & - & - & - & - & - & - \\
\hline & His204 & His204 & His204 & His204 & His204 & His204 & His204 & His204 \\
\hline & Asn205 & Asn 205 & Asn 205 & Asn 205 & Asn 205 & Asn 205 & Asn 205 & Asn 205 \\
\hline & His208 & His208 & His208 & His208 & His208 & His208 & His208 & His208 \\
\hline & Arg209 & Arg209 & Arg209 & Arg209 & Arg209 & Arg209 & Arg209 & Arg209 \\
\hline & Met215 & Met215 & - & - & - & - & - & Met215 \\
\hline & Gly216 & Gly216 & - & Gly216 & Gly216 & Gly216 & - & Gly216 \\
\hline & Val217 & Val217 & - & Val217 & Val217 & Val217 & - & Val217 \\
\hline & Val218 & Val218 & Val218 & Val218 & Val218 & Val218 & Val218 & Val218 \\
\hline & Ala221 & Ala221 & Ala221 & Ala221 & Ala221 & Ala221 & Ala221 & Ala221 \\
\hline & - & Phe227 & Phe227 & Phe227 & Phe227 & Phe227 & Phe227 & - \\
\hline$\% B S S$ & 100 & 100 & 70 & 90 & 90 & 90 & 70 & 100 \\
\hline
\end{tabular}

Note: K: control; 1: caffeic acid; 2: cinnamic acid; 3: ferulic acid; 4: genistein; 5: kaempferol; 6: p-coumaric acid; 7: vanilic acid; Bold letter: Residue bind by hydrogen bond; Regular letter: Residue bind by hydrophobic interaction
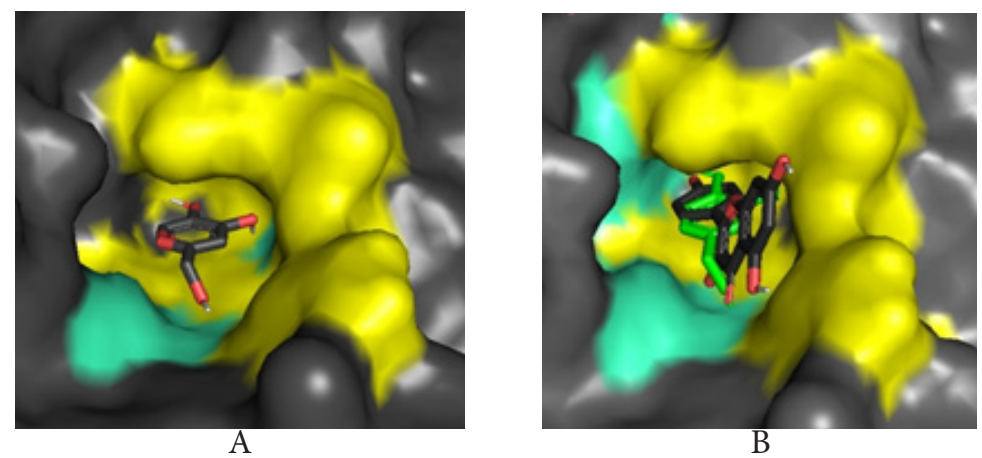

Figure 2 3D visualization of molecular docking result using PyMOL. Blue region shows amino acids interact by hydrogen bond; yellow region shows hydrophobic interaction. A) Visualization of kojic acid inside active side of tyrosinase. B) Visualization of kaempferol inside active side of tyrosinase. Kojic acid as comparison is shown in green.

ketika tertambat pada entrance sisi aktif, asam kojat akan terstabilkan oleh interaksi dengan residu Phe197, Pro201, Asn205, dan Arg209. Ketika tertambat pada sisi aktif, asam kojat akan terstabilkan oleh interaksi $\pi-\pi$ dengan residu His208 yang berkoordinasi dengan $\mathrm{CuB}$ seperti substrat tirosinase. Hal ini menunjukkan bahwa ligan kontrol asam kojat dan kaempferol telah tertambat pada residu entrance sisi aktif yaitu Asn 205 dan Arg 209 juga pada sisi aktif dari tirosinase yaitu His 208. Visualisasi posisi ligan pada sisi aktif tirosinase menunjukkan bahwa kaempferol sudah menempati sisi aktif yang sama dengan ligan kontrol asam kojat (Figure 2).

Ligan dengan BSS paling tinggi adalah asam kafeat, ligan dengan $\Delta G$ terendah adalah kaempferol. Hal ini membuktikan bahwa jumlah interaksi residu dan kesamaan residu dengan ligan kontrol bukan satu- 
satunya faktor yang menentukan nilai $\Delta \mathrm{G}$. Nilai $\Delta \mathrm{G}$ dipengaruhi oleh berbagai faktor misalnya interaksi elektrostatis, lipofilisitas/ hidrofobisitas, kesamaan bentuk, juga faktor lain seperti entropi dan perubahan konformasi. Faktor ini memungkinkan kampferol memiliki $\Delta G$ lebih negatif dari asam kafeat dan asam vanilat karena memiliki lebih banyak ikatan hidrogen. Setiap ikatan hidrogen meningkatkan afinitas sebesar 0,48 sampai $1,55 \mathrm{kkal} / \mathrm{mol}$ untuk ikatan netral dan 2,39 sampai 4,78 kkal/mol untuk ikatan bermuatan atau jembatan garam. Interaksi hidrofobik juga terkadang dapat meningkatkan afinitas lebih dari ikatan hidrogen (Balle dan Liljefors 2016).

\section{KESIMPULAN}

Penelusuran senyawa aktif $S$. platensis menunjukkan bahwa $S$. platensis memiliki senyawa asam kafeat, asam sinamat, asam ferulat, genistein, kaempferol, asam p-kumarat, dan asam vanilat yang berdasarkan analisis penambatan molekuler memiliki afinitas lebih baik dari inhibitor tirosinase yang sudah dipatenkan yaitu asam kojat. Senyawa yang memiliki potensi sebagai inhibitor tirosinase terbaik adalah kaempferol karena memiliki nilai $\Delta \mathrm{G}$ paling negatif yaitu sebesar $-7.0 \mathrm{kkal} /$ mol.

\section{DAFTAR PUSTAKA}

Balle T, Liljefors T. 2016. Molecular Recognition. Di dalam Strømgaard K, Krogsgaard-Larsen P, Madsen U (Eds.), Textbook of Drug Design and Discovery (5th ed.). CRC Press.

Costa JAV, Barbieri Moro GM, de Moraes Vaz Batista Filgueira D, Corsini E, Bertolin TE. 2017. The potential of Spirulina and its bioactive metabolites as ingested agents for skin care. Industrial Biotechnology. 13(5): 244-252.

Costa LG. 2013. Toxic Effects of Pesticides. Di dalam Klaassen CD (Ed.), Casarett \& Doull's Toxicology: The Basic Science of Poisons (8th ed.). McGraw-Hill Education.

da Silva MF, Casazza AA, Ferrari PF, Aliakbarian B, Converti, A, Bezerra RP, Porto ALF, Perego P. 2017. Recovery of phenolic compounds of food concern from Arthrospira platensis by green extraction techniques. Algal Research. 25: 391-401.

Deri B, Kanteev M, Goldfeder M, Lecina D, Guallar V, Adir N, Fishman A. 2016. The unravelling of the complex pattern of tyrosinase inhibition. Scientific Reports. 6(1): $1-10$.

Di L, Kerns EH. 2016. Drug-Like Properties: Concepts, Structure Design and Methods from ADME to Toxicity Optimization (2nd ed.). Elsevier.

Eaton DL, Gilbert SG. 2013. Principles of Toxicology. Di dalam Klaassen CD (Ed.), Casarett \& Doull's Toxicology: The Basic Science of Poisons (8th ed.). McGraw-Hill Education.

Ghose AK, Viswanadhan VN, Wendoloski JJ. 1999. A knowledge-based approach in designing combinatorial or medicinal chemistry libraries for drug discovery. 1. A qualitative and quantitative characterization of known drug databases. Journal of Combinatorial Chemistry. 1(1): 55-68.

Khan S, Nazir M, Raiz N, Saleem M, Zengin G, Fazal G, Saleem H, Mukhtar M, Tousif MI, Tareen RB, Abdallah HH, Mahomoodally FM. 2019. Phytochemical profiling, in vitro biological properties and in silico studies on Caragana ambigua stocks (Fabaceae): A comprehensive approach. Industrial Crops and Products. 131: 117124.

Klaunig JE. 2013. Chemical Carcinogenesis. In Klaassen CD (Ed.), Casarett \& Doull's Toxicology: The Basic Science of Poisons (8th ed.). McGraw-Hill Education.

Klejdus B, Kopecký J, Benešová L, Vacek J. 2009. Solid-phase/supercritical-fluid extraction for liquid chromatography of phenolic compounds in freshwater microalgae and selected cyanobacterial species. Journal of Chromatography A. 1216(5): 763-771.

Lipinski CA, Lombardo F, Dominy BW, Feeney PJ. 1997. Experimental and computational approaches to estimate solubility and permeability in drug discovery and development settings. 
Advanced Drug Delivery Reviews. 23: (13): 3-25.

Lupatini AL, Colla LM, Canan C, Colla E. 2017. Potential application of microalga Spirulina platensis as a protein source. Journal of the Science of Food and Agriculture. 97(3): 724-732.

Mustarichie R, Levita J, Febriani D. 2013. In-silico study of curcumin, demethoxycurcumin, and xanthorrizol as skin whitening agents. World Journal of Pharmaceutical Sciences. 1(3): 72-80.

Ozdemir G, Ulku Karabay N, Dalay MC, Pazarbasi B. 2004. Antibacterial activity of volatile component and various extracts of Spirulina platensis. Phytotherapy Research. 18(9): 754-757.

Papalia T, Sidari R, Panuccio MR. 2019. Impact of different storage methods on bioactive compounds in Arthrospira platensis biomass. Molecules. 24(15): 2810.

Ramsden CA, Riley PA. 2014. Tyrosinase: The four oxidation states of the active site and their relevance to enzymatic activation, oxidation and inactivation. Bioorganic and Medicinal Chemistry. 22(8):23882395.

Reddy SB, Vashi NA. 2018. Pathophysiology of Hyperpigmentation. Di dalam Rigopoulos D, Katoulis AC (Eds.), Hyperpigmentation. CRC Press.

Roncaglioni A, Toropov AA, Toropova AP, Benfenati E. 2013. In silico methods to predict drug toxicity. Current Opinion in Pharmacology. 13(5): 802-806.

Sahin SC. 2018. The potential of Arthrospira platensis extract as a tyrosinase inhibitor for pharmaceutical or cosmetic applications. South African Journal of Botany. 119: 236-243.

Trott O, Olson AJ. 2009. AutoDock Vina: Improving the speed and accuracy of docking with a new scoring function, efficient optimization, and multithreading. Journal of Computational Chemistry. 31(2): 455-461.

Yang H, Lou C, Sun L, Li J, Cai Y, Wang Z, Li W, Liu G, Tang Y. 2019. admetSAR 2.0: webservice for prediction and optimization of chemical ADMET properties. Bioinformatics. 35(6): 1067-1069. 